Indonesian Journal of
Mathematics and Natural Sciences Education
p-ISSN: 2721-172X e-ISSN: 2721-1746
Vol. 1 No. 3 Th 2020; hal 175 -181
http://mass.iain-jember.ac.id

\title{
Kemampuan Representasi Matematis Siswa SMP melalui Pendekatan Pembelajaran RME dan CTL pada Sub Pokok Bahasan Kubus dan Balok
}

\author{
Iwan Eko Setianto $^{1^{*}}$, Risnanosanti ${ }^{1}$ \\ ${ }^{1}$ Program Studi Matematika, Fakultas Keguruan dan Ilmu Pendidikan, Universitas Muhammadiyah Bengkulu \\ *E-mail: iwanbagas51@gmail.com
}

\begin{abstract}
Abstrak
Penelitian ini bertujuan untuk mengetahui apakah ada perbedaan kemampuan representasi matematis siswa yang diajarkan menggunakan pendekatan pembelajaran Realistic Mathematic Education (RME), Contextual Teaching And Learning (CTL), dan konvensional. Jenis penelitian ini adalah penelitian ekperimen semu. Populasi penelitian ini adalah seluruh kelas VIII SMPN 24 Bengkulu Utara dengan sampel yaitu siswa kelas VIII A sebagai kelas eksperimen I, siswa kelas VIII B sebagai kelas eksperimen II, dan siswa kelas VIII C sebagai kelas kontrol. Data dikumpulkan dengan tes kemampuan representasi matematis siswa kemudian di analisis dengan uji Anava. Hasil analisis uji Anava menunjukkan adanya perbedaan yang signifikan antara kemampuan representasi matematis siswa yang diajar melalui pendekatan RME dengan pendekatan CTL, maupun dengan pendekatan konvensional. Hasil penelitian menunjukan bahwa kelas yang diajar menggunakan pendekatan pembelajaran RME diperoleh rata-rata skor akhir kemampuan representasi matematis siswa sebesar 16,8. Kelas yang diajarkan dengan pendekatan pembelajaran CTL diperoleh rata-rata skor akhir kemampuan representasi matematis siswa sebesar 17,9. Sedangkan dikelas yang diajarkan dengan pembelajaran konvensional diperoleh rata-rata skor akhir kemampuan representasi matematis siswa sebesar 13,80. Hasil uji BNT (Beda Nyata Terkecil) diperoleh bahwa perlakuan yang memberikan hasil yang berbeda adalah perlakuan antara eksperimen I dengan kontrol dan eksperimen II dengan kontrol.
\end{abstract}

Kata Kunci: CTL, Representasi Matematis, RME

\section{PENDAHULUAN}

Untuk memajukan ilmu pengetahuan dan teknologi, matematika memegang peranan yang sangat penting karena hampir semua ilmu pengetahuan dan teknologi memanfaatkan ilmu matematika. Hal ini sejalan menurut (As'aril, 2017) Matematika merupakan ilmu universal yang berguna bagi kehidupan manusia dan juga mendasari perkembangan teknologi modern, serta mem- punyai peran penting dalam berbagai ilmu disiplin, dan memajukan daya pikir manusia.

Matematika diberikan sejak dini di sekolah untuk membekali anak dengan kemampuan berpikir logis, analitis, sistematis, kritis dan kreatif, serta kemampuan berkerja sama. Matematika dapat membekali semua kemampuan tersebut sebagai modal penting yang diperlukan peserta didik. Kemampuankemampuan yang diperlukan dalam 
matematika: pemahaman, penalaran, koneksi, representasi dan penyelesaian masalah. Tujuan pembelajaran matematika menurut (Kemendikbud, 2013) adalah agar siwa mampu dalam memecahkan masalah, menggunakan penalaran, komunikasi, koneksi dan representasi.

Selain itu tujuan pembelajaran matematika menurut kurikulum 2013 salah satunya yaitu siswa diharapkan memiliki kemampuan representasi matematis yang meliputi kemampuan siswa dalam membuat suatu model dari suatu masalah ke dalam bentuk baru baik secara verbal, tulisan, tabel ataupun grafik. Hal ini seperti yang tercantum pada Peraturan Menteri Pendidikan dan Kebudayaan No. 58 Tahun 2014. Sejalan Pendapat (Ramziah, 2016) kemampuan representasi matematis merupakan kemampuan yang menuntut siswa untuk dapat membuat suatu model dari suatu masalah ke dalam bentuk baru baik secara verbal, tulisan, grafik, tabel ataupun gambar.

Kemampuan representasi matematis merupakan salah satu kompetensi yang harus dicapai dalam pembelajaran matematika. Kemampuan representasi matematis diperlukan siswa untuk bepikir matematis dan mengkomunikasikan ide-ide matematika dalam berbagai cara. Hal ini sejalan dengan (Anarulita, 2013) bahwa kemampuan representasi matematis sangat diperlukan dalam matematika, karena untuk memberikan kelancaran siswa dalam membangun konsep dan berfikir matematik serta memiliki kemampuan dan representasi yang kuat dan fleksibel yang dibangun oleh guru melalui representasi matematis.
Dalam pembelajaran matematika siswa diharapkan mampu untuk berpikir matematis dan mengungkapkan ide-ide yang dimiliki, namun pada kenyataannya sebagian besar hal itu belum terlaksana sehingga banyak siswa yang mengalami kesulitan dalam representasi matematis. Penyebab dari tidak terlaksananya hal tersebut karena pembelajaran matematika pada umumnya guru masih memberikan atau menyampaikan materi secara langsung dan dalam pengerjaan suatu masalah siswa diberi tahu secara langsung penyelesaianya. Hal ini sejalan dengan pendapat (Russefendi, 2018) yang menyatakan bahwa proses pembelajaran matematika selama ini, pada umumnya siswa mempelajari matematika hanya diberi tahu oleh gurunya bukan melalui kegiatan eksplorasi.

Sependapat dengan (Herdiman, 2018) bahwa pada umumnya proses pembelajaran di sekolah sering ditemukan hanya untuk mencapai tujuan tingkat rendah saja yakni dalam mengetahui, memahami dan menggunakan, akan tetapi belum mampu menimbulkan kebiasaan menggunakan kemampuan matematika yang lebih tinggi. Kondisi ini menyebabkan pemahaman siswa terhadap konsep-konsep matematika sangat kurang, sehingga berdampak pada tidak adanya proses dari representasi matematis siswa dalam pembelajaran matematika.

Berdasarkan wawancara yang dilakukan dengan salah satu guru mata pelajaran matematika (2019) di SMPN 24 Bengkulu Utara, menyatakan bahwa pembelajaran yang diterapkan masih menggunakan pembelajaran langsung. Kemampuan representasi matematis 
masih rendah, karena siswa tanpa memahami maksud, isi dan kegunaannya dari soal yang diberikan. hal tersebut terlihat dari kesulitan siswa dalam menerapkan konsep pembelajaran ke persoalan yang diberikan oleh guru.

Dalam proses pembelajaran matematika untuk mengembangkan kemampuan representasi matematis siswa, maka dapat digunakan suatu model pembelajaran yang tidak hanya meningkatkan pengetahuan siswa saja, namun juga membantu siswa untuk befikir matemamatis dan mengkomunikasikan ide-ide matematika dalam berbagai cara dan mencari solusi yang benar dari suatu permasalahan yang dihadapinya. Salah satu cara untuk mengatasinya adalah pemilihan model pembelajaran dengan memperhatikan kondisi pembelajaran sehingga dapat meningkatkan kemampuan siswa. Maka model pembelajaran yang dapat digunakan adalah pendekatan pembelajaran Contextual teaching and Learning (CTL) dan pendekatan pembelajaran Realistic Mathematic Education (RME).

Pendekatan pembelajaran RME adalah pembelajaran yang menyajikan materi yang difokuskan pada kehidupan sehari-hari. Pada model pembelajaran ini lebih menekankan pada proses keterampilan, berdiskusi, berkolaborasi, berargumentasi untuk menemukan jawaban atau solusi dari suatu permasalahan. Sejalan menurut Hadi (2017) pendekatan pembelajaran RME adalah model pembelajaran yang dimulai dengan meyajikan sesuatu yang riil (nyata) di kehidupan sehari-hari untuk diajarakan kepada siswa. Oleh karena itu pendekatan pembelajaran RME cocok untuk mengembangkan kemampuan representasi matematis siswa dalam pembelajaran matematika.

Sedangkan menurut (Afriasyah, 2018) pendekatan pembelajaran CTL adalah pendekatan pembelajaran yang menyajikan materi dengan situasi dunia nyata kemudian dipaparkan dalam bentuk persoalan/pertanyaan cerita dan memiliki kesulitan tersendiri bagi siswa. Selain itu siswa dituntut untuk memahami kaitan antara materi karena bersifat kontekstual untuk menemukan solusi dari permasalahan tersebut.

Dengan melihat penjelasan tersebut, maka dilakukan penelitian mengenai kemampuan representasi matematis melalui pendekatan pembelajaran RME dan CTL pada Sub pokok bahasan kubus dan balok.

\section{METODE}

Jenis penelitian ini adalah penelitian eksperimen semu. Populasi pada penelitian seluruh siswa kelas VIII SMP Negeri 24 Bengkulu Utara, yang berjumlah 152 orang dari lima kelas. Sedangkan yang menjadi populasinya adalah kelas VIII A (eksperimen I/ pendekatan RME), kelas VIII B (eksperimen II/ pendekatan CTL), dan kelas VIII C (perlakuan kontrol/ pendekatan konvensional). Jumlah sampel siswa yang terlibat pada penelitian ini sejumlah 92 orang (Tabel 1)

Tabel 1. Jumlah Sampel

\begin{tabular}{ccc}
\hline No. & \multicolumn{1}{c}{ Kelas } & Jumlah Siswa \\
\hline$(1)$ & $(2)$ & $(3)$ \\
\hline 1. & Eksperimen I (VIII A) & 30 \\
2. & Eksperimen II (VIII B) & 30 \\
3. & Kontrol (VIII C) & 32 \\
\hline & Total sampel & 92 \\
\hline
\end{tabular}


Data dikumpulkan dengan tes kemampuan representasi matematis siswa kemudian dianalisis dengan OneWay Annova.

\section{HASIL DAN PEMBAHASAN}

Hasil analisis uji anava ada perbedaan yang signifikan antara kemampuan representasi matematis siswa yang diajar melalui pendekatan RME, pendekatan CTL dan pendekatan konvensional. Hasil penelitian (Gambar 1) menunjukkan bahwa kelas yang diajar dengan pendekatan RME diperoleh ratarata skor kemampuan representasi matematis siswa sebesar 16,8. Kelas yang diajarkan dengan pendekatan CTL diperoleh rata-rata skor kemampuan representasi matematis siswa sebesar 17,9. Sedangkan kelas konvensional diperoleh rata-rata skor kemampuan representasi matematis siswa sebesar 13,8 .

Dari hasil analisis statistik menggunakan One-Way Annova diketahui bahwa kelas eksperimen I tidak berbeda signifikan terhadap kelas eksperimen II. Namun, baik kelas eksperimen I maupun kelas eksperimen II berbeda signifikan terhadap kelas kontrol.
Kelas dengan pembelajaran menggunakan pendekatan RME memiliki rata-rata skor kemampuan representasi matematis yang berbeda signifikan terhadap kelas kontrol. Hal ini menunjukkan bahwa pendekatan RME dapat memberikan pengaruh positif pada kemampuan representasi matematis siswa pada sub pokok bahasan kubus dan balok.

Menurut Hobri (2009) pembelajaran dengan pendekatan RME dioperasionalkan melalui beberapa karakteristik, yakni menggunakan masalah kontekstual, menggunakan model, menggunakan kontribusi siswa, interaktivitas, dan terintegrasi dengan topik lainnya.

Pada pembelajaran dengan pendekatan RME siswa diminta untuk mendapatkan konsep materi yang dipelajari secara mandiri, dan menyimpulkan materi yang dipelajarinya. Hal ini mendukung penyelesaian masalah dan representasi pada pembelajaran RME. Selain itu kemampuan guru dalam merencanakan dan menerapkan pembelajaran RME juga berpengaruh pada hasil belajar. Semakin baik kinerja guru dalam pembelajaran RME maka akan semakin baik pula hasil yang diharapkan.

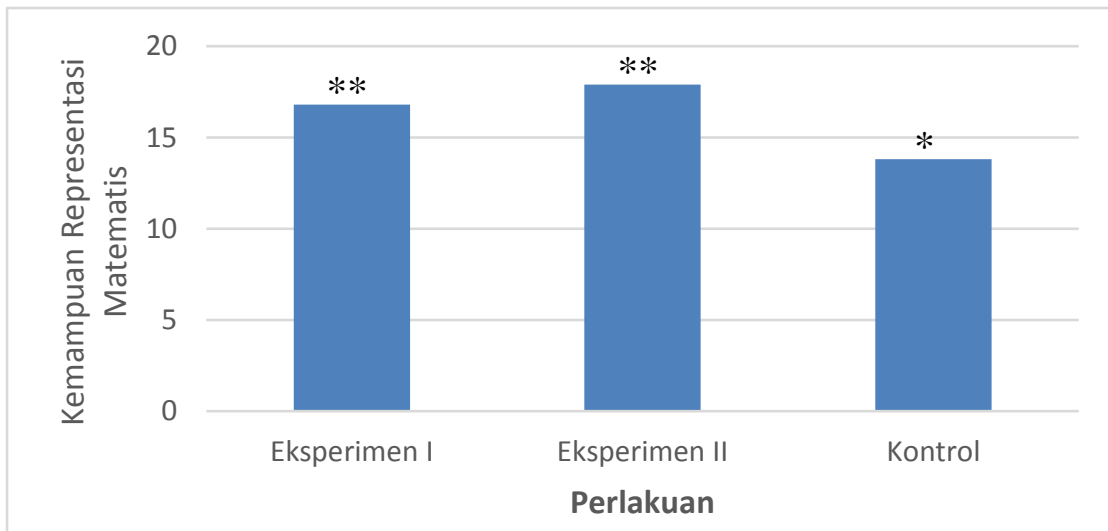

Gambar 1. Histogram Kemampuan Representasi Matematis 
Asmin (2001) mengungkapkan bahwa pembelajaran RME dapat membuat siswa menjadi lebih senang dan termotivasi karena pembelajaran menggunakan realitas kehidupan. Peningkatan motivasi belajar menjadi salah satu pemicu meningkatnya kemampuan representasi matematis. Menurut Suprihatin (2015) Motivasi belajar yang dimiliki seseorang akan menentukan kualitas yang ditampilkannya, baik dalam konteks belajar, bekerja, maupun dalam kehidupan yang lainnya.

Hasil penelitian ini sejalan dengan Astriningsih (2015) yang menemukan bahwa representasi matematis dari pembelajaran dengan menggunakan pendekatan RME lebih baik secara signifikan daripada pembelajaran konvensional. Begitu juga dengan hasil penelitian Ichwatun (2015) yang membuktikan bahwa hasil belajar matematika dengan pendekatan RME berbasis scientific approach lebih tinggi dari hasil belajar menggunakan pendekatan konvensional.

Pada pendekatan pembelajaran CTL diawali dengan pemberian masalah kepada siswa, sehingga siswa dituntut dapat memahami materi yang sifatnya kontekstual. Sedangkan pembelajaran RME siswa belajar untuk menggali masalah, berargumentasi, berdiskusi dan mencari informasi dalam menyelesaikan masalah bersama-sama. Guru hanya sekedar fasilitator dalam pelaksanaan pembelajaran. Sehingga pendekatan pembelajaran RME dan pendekatan pembelajaran CTL dapat mengembangkan kemampuan representasi matematis siswa.
Berdasarkan data hasil penelitian, pendekatan pembelajaran CTL memberikan hasil kemampuan representasi matematis tertinggi dari pembelajaran RME maupun konvensional. Meskipun tidak berbeda signifikan dengan kemampuan representasi matematis pada pembelajaran RME, namun ratarata skor menunjukkan angka yang lebih tinggi. Hal ini sejalan dengan hasil penelitian Damayanti \& Afriansyah (2018) yang menemukan bahwa kemampuan representasi matematis siswa dengan pendekatan CTL lebih baik dari PBL.

Dibandingkan dengan kemampuan representasi matematis siswa kelas kontrol (pendekatan konvensional), kemampuan representasi matematis siswa kelas eksperimen II (menggunakan pendekatan PBL) berbeda secara signifikan. Hasil ini sejalan dengan penelitian Andriansyah (2014) yang membuktikan bahwa kemampuan representasi matematis siswa yang pembelajarannya diterapkan pendekatan CTL memiliki nilai rata-rata yang lebih tinggi dan signifikan dari siswa yang pembelajarannya konvensional.

Pada pembelajaran matematika sub pokok bahasan kubus dan balok dengan pendekatan CTL, siswa tidak hanya menerima informasi dari guru. Pada penerapan pembelajaran CTL, siswa memiliki peran aktif dalam mencari dan memahami informasi terkait materi yang dipelajari. Menurut Sanjaya (2012) pembelajaran CTL merupakan pembelajaran yang menekankan pada proses keterlibatan siswa secara penuh untuk dapat menerapkannya dalam kehidupan sehari-hari. 
Indonesian Journal of Mathematics and Natural Science Education, 1 (3), 2020

Iwan Eko Setianto, Risnanosanti

\section{SIMPULAN}

Berdasarkan analisis dan pembahasan yang telah diuraikan pada bab sebelumnya, maka dari penelitian ini dapat ditarik kesimpulan bahwa.

Ada perbedaan yang signifikan antara kemampuan representasi matematis siswa yang diajar melalui model RME, model pembelajaran CTL dan pembelajaran konvensional pada sub pokok bahasan kubus dan balok di kelas VIII SMPN 24 Bengkulu Utara.

Model pembelajaran CTL memberikan hasil yang lebih baik dari model pembelajaran RME dan model pembelajaran CTL memberikan hasil yang lebih baik dari model pembelajaran konvensional untuk meningkatkan kemampuan representasi matematis siswa pada sub pokok bahsan kubus dan balok di kelas VIII SMPN 324 Bengkulu Utara.

\section{DAFTAR PUSTAKA}

Anarulita, A. A., Multono, M., \& Sunarmi. (2013). Keefektifan Pembelajaran Model Designed Student-Centered Instructional terhadap Kemampuan Representasi Peserta Didik. Unnes Journal of Mathematics Education 2 (3): 60 - 65.

Andriansyah, F. (2014). Pengaruh Pendekatan Kontekstual terhadap Kemampuan Representasi Matematis Siswa. Skripsi. Universitas Islam Negeri Syarif Hidayatullah Jakarta.

Asmin. (2009). Implementasi Matematis Realistic (PMR) dan Kendala yang muncul di Lapangan. Jakarta: Balitbang DIKNAS.
As'aril, (2017). Ilmu Pendidikan Perspektif Kontekstual. Jakarta: Ar.Ruzz Media.

Damayanti, R. \& Afriansyah, E. A. (2018). Perbandingan Kemampuan Representasi Matematis Siswa antara Contextual Teaching and Learning dan Problem Based Learning. Jurnal Ilmiah Pendidikan Matematika. 7 (1): 30 - 39.

Gitriani, R., Aisah, S., Hendriana, H., \& Herdiman, I. (2018). Pengembangan Lembar Kerja Siswa Berbasis Pendekatan Kontekstual pada Materi Lingkaran Untuk Siswa SMP. Jurna; Review Pembelajaran Matematika 3 (1): 40 48.

Hobri. (2009). Model-model Pembelajaran Inovatif. Jember: Center for Society Studies.

Ichwatun, A. (2015). Pengaruh Metode RME Berbasis Scientific Approach terhadap Hasil Belajar Siswa pada Mapel Matematika Materi Sifat Bangun Datar Kelas III MI NU 05 Taman Gede Kec. Gumuh Kab, Kendal. Skripsi. Universitas Islam Negeri Walisongo Semarang.

Kemendikbud, (2013). Peraturan Menteri Pendidikan Dan Kebudayaan Nomor 58 Tahun 2014 Tentang Kurikulum SMP.

Ruseffendi, E. T. (2018). Dasar-Dasar Matematika Modern dan Kom-puter Untuk Guru. Bandung: Tarsito.

Ramziah, S. (2016). Peningkatan Kemampuan Representasi Matematis Siswa Kelas X2 SMAN 1 Gedung Meneng Menggunakan 
Bahan Ajar Matriks Berbasis

Pendekatan Saintifik. Mosharafa:

Jurnal Pendidikan Matematika 5 (2):

$138-147$

Sanjaya, W. (2012). Strategi Pembelajaran

Berorientasi Standar Proses

Pendidikan. Jakarta: Kencana

Prenada Media Group.

\section{PROFIL SINGKAT}

1. Nama : Iwan Eko Setianto

TTL : Air Petai, 1 Juni 1997

Alamat : Ds. Air Petai, Rw 1, Rt 1.

Kec. Putri Hijau, Kab. Bengkulu Utara.

2. Nama : Dr. Risnanosanti, M.Pd.

TTL : Palembang, 21 Januari

1968.

Alamat : Merpati 5, Keluran Rawa

Makmur, Kota Bengkulu 